\title{
Pengaruh Substitusi Susu Skim oleh Tepung Kedelai Sebagai Binder Terhadap Beberapa Sifat Fisik Sosis yang Berbahan Dasar Surimi-like Kerbau
}

\author{
Effect of substitusion skim milk by soybean meal as binder \\ on physical properties of sausage made from Buffallo Surimi-like \\ Olfa Mega \\ Jurusan Peternakan Fakultas Pertanian Universitas Bengkulu \\ Jl. Raya Kandang Limun Bengkulu Telp. (0736) 21170 Pst 219.
}

\begin{abstract}
The aim of this research was to study the effect of substitusion skim milk by soybean meal as binder on the sausage physical properties made from buffallo surimi-like. The research was designed as completely randomized design at 4 treatments and 3 replications, those were P1 (6\% Skim Milk (SS) : 0\% Soybean Meal (TK)), P2 (4\% SS:2\%TK), P3 ( $2 \%$ SS:4\%TK) and P4 (0\% SS : 6\% TK). Data were analyzed using analysis of variance and Duncan Multiple of Range Test. The results showed that substution skim milk by soybean meal significantly $(\mathrm{P}<0,01)$, increased water holding capacity and decreased firmness and cooking loss, while $\mathrm{pH}$ and colors of sausage were not significantly different. Water holding capacity was 83,82\% (P1), 94,28\% (P2), 90,71\% (P3) and 91,17\% (P4), while firmness at each treatment was $0,31 \mathrm{~kg} / \mathrm{mm}(\mathrm{P} 1), 0,26 \mathrm{~kg} / \mathrm{mm}$ (P2 and P3) and 0,18 kg/mm (P4). Cooking loss decrease at P1 (7,20\%), P2 (5,17\%), P3 (4,53) and P4 (2,53).
\end{abstract}

Key words : binder, sausage, physic properties, surimi-like

\begin{abstract}
ABSTRAK
Penelitian bertujuan untuk mempelajari pengaruh substitusi susu skim oleh tepung kedelai sebagai binder terhadap karakteristik fisik sosis dengan bahan baku surimi-like kerbau. Percobaan menggunakan Rancangan Acak Lengkap, yang terdiri dari empat perlakuan dan tiga ulangan. Perlakuan tersebut adalah P1 (6\% susu skim (SS):0\% tepung kedelai (TK), P2 (4\% SS: 2\% TK), P3 (2\%SS : 4\% TK) dan P4 (6\% SS : 0\% TK). Hasil Penelitian menunjukkan substitusi susu skim oleh tepung kedelei sangat nyata $(\mathrm{P}<0,01)$ meningkatkan daya mengikat air, menurunkan kekerasan dan susut masak sosis tetapi tidak mempengaruhi nilai $\mathrm{pH}$ dan warna sosis. Daya mengikat air berturut-turut pada perlakuan P1, P2, P3 dan P4 adalah 83,81\%, 94,28\%,90,71\% dan 91,17\% dengan nilai kekerasan adalah 0,31 kg/mm (P1), 0,26 kg/mm (P2 dan P3) dan 0,18 kg/mm (P4) sedangkan susut masak untuk P1 (7,20\%), P2 (5,17\%), P3 (4,53) dan P4 (2,53).
\end{abstract}

Kata kunci : binder, sosis, sifat fisik, surimi-like

\section{PENDAHULUAN}

Pangan adalah kebutuhan dasar manusia yang pemenuhannya menjadi hak azasi setiap rakyat Indonesia. Berdasarkan evaluasi Susenas 2003, tingkat konsumsi pangan hewani masyarakat Indonesia baru sekitar 58\% dari kebutuhan (Dirjen Bina Produksi Peternakan, 2004). Artinya, sebagian besar masyarakat Indonesia masih bertumpu pada bahan pangan nabati untuk pemenuhan gizinya. Hingga saat ini produk olahan hasil ternak di Indonesia masih terbatas, sehingga untuk memenuhi kebutuhan nasional masih harus impor (Dirjen Bina Produksi Peternakan, 2004). Untuk penyediaan hasil ternak dalam jangka panjang, perlu optimalisasi seluruh segmen kegiatan industri peternakan, yaitu: (1) industry 
primer seperti pembibitan dan budidaya ternak, (2) industri sekunder dalam kegiatan pasca panen, dan (3) industri tersier di bidang distribusi dan pemasaran (Chamdi, 2004). Goldberg (1991) memprediksikan bahwa dalam agribisnis global tahun 2000-2028, fokus kegiatan dan penyerapan dana terbesar adalah untuk industri sekunder dan tersier. Oleh sebab itu, peranan teknologi pangan sebagai inti industri sekunder peternakan dalam pengembangan produk olahan hasil ternak harus ditingkatkan untuk antisipasi kompetisi global saat ini dan di masa depan.

Ternak kerbau mempunyai peran cukup signifikan dalam program P2SDS (Percepatan Pencapaian Swasembada Daging Sapi pada Tahun 2010) yang dicanangkan oleh Ditjen Peternakan. Dengan jumlah populasi pada 2007 sejumlah 2,5 juta ekor, maka peranan ternak kerbau dalam program P2SDS sebesar $22 \%$ dan ternak sapi sebesar $78 \%$. Tetapi jika dilihat dari sumbangan daging maka kontribusi kerbau sejumlah 41 ribu ton per tahun, atau hanya sekitar $8 \%$. Untuk itu perlu upaya untuk meningkatkan konsumsi daging kerbau baik dalam bentuk daging segar maupun daging olahan.

Sosis adalah produk daging olahan yang cukup populer khususnya di kalangan anak-anak dan remaja. Bahan utama sosis biasanya berasal dari daging sapi dan daging ayam. Daging kerbau mempunyai peluang yang sama untuk digunakan sebagai bahan utama pembuatan sosis. Rasa daging kerbau hampir sama dengan daging sapi tetapi berwarna agak gelap, daging pada umumnya liat, karena disembelih pada umur tua, serabut otot kasar dan lemaknya putih. Nikumi (surimi-like) merupakan produk antara yang mempunyai sifat elastisitas yang tinggi, biasanya dijadikan bahan baku dalam pembuatan sosis, nugget maupun bakso.

Selain daging, dalam pembuatan sosis bahan pengikat (binder) sangat mempengaruhi kualitas sosis. Bahan pengikat mempunyai kandungan protein tinggi seperti kasein (protein susu) dan susu skim. Tujuan penambahan bahan pengikat diantaranya adalah membentuk dan menstabilkan emulsi, meningkatkan daya mengikat air dan menurunkan susut masak. Tepung kedelai mengandung protein 56\% dengan harga yang jauh lebih murah dibanding susu skim, kasein dan isolate protein kedelai yang kandungan proteinnya $90-95 \%$. Substitusi susu skim dengan tepung kedelai diharapkan dapat memberikan karakteristik sosis yang baik.

Penelitian ini bertujuan untuk mempelajari sifat-sifat fisik sosis dengan bahan baku surimi-like kerbau dengan menggunakan tepung kedelai sebagai binder menggantikan susu skim.

\section{MATERI DAN METODE}

Penelitian menggunakan daging kerbau (otot bagian paha belakang) yang diperoleh di RPH di Kota Bengkulu. Bahan lain yang digunakan adalah sukrosa dan polifosfat sebagai antidenaturan, lemak sapi, susu skim, tepung kedelai, tepung sagu, tepung gandum, gula, garam dapur $(\mathrm{NaCl})$, STTP (sodium tripoli phosphat), bumbu (merica, pala, bawang putih) es batu (air es), selongsong sosis dan bahanbahan lain yang digunakan untuk analisa kimia. Peralatan yang digunakan antara lain alat penggiling daging ( food processeor), alat pengisi casing (stuffer), penggiling daging (meat mincer), termometer, blender, timbangan, alat pengepres (vegetable presser) yang dilapisi kain kasa dengan diameter lubang 0,5 mesh, kompor, pisau, dandang, wadah 
plastik, benang dan peralatan lain yang digunakan untuk analisa-analisa variabel.

\section{Pelaksanaan Penelitian}

Daging kerbau terlebih dahulu
dibuat nikumi (surimi-like) dengan komposisi antidenaturan 5\% sukrosa dan 0,2\% polifosfat (Mega, 2010). Nikumi kerbau beku dithawing pada suhu chilling \pm $5^{\circ} \mathrm{C}$ selama 60 menit, kemudian ditempatkan pada suhu ruang. Selanjutnya dilakukan penggilingan nikumi; sebanyak 300 gram nikumi digunakan untuk setiap ulangan (kelompok) percobaan ditambahkan $10 \%$ lemak sapi dan $10 \%$ es batu digiling selama \pm 1 menit (Pencampuran 1). Ditambahkan es batu $15 \%$, bahan pengisi, pengikat (sesuai perlakuan) dan bumbu-bumbu lalu digiling kembali selama 3 menit (Pencampuran II). Adonan diisikan kedalam selongsong (casing) dengan stuffer lalu dimasak dengan cara dikukus pada suhu $65^{\circ} \mathrm{C}$ selama \pm 45 menit.

Perlakuan yang diberikan ádalah level penggunaan bahan pengikat (binder) yaitu tepung kedelai sebagai substitusí susu skim dengan empat taraf kombinasi. Keempat perlakuan tersebut adalah sebagai berikut :

$\mathrm{P} 1=6 \%$ Susu Skim $+0 \%$ tepung kedelai

$\mathrm{P} 2=4 \%$ Susu Skim $+2 \%$ tepung kedelai

P3 $=2 \%$ Susu Skim $+4 \%$ tepung kedelai

$\mathrm{P} 4=0 \%$ Susu Skim $+6 \%$ tepung kedelai

Komposisi bahan dalam pembuatan sosis disajikan dalam Tabel 1 berikut :

Susu skim yang digunakan didapat dari supermarket, komposisinya ádalah sbb: protein $34,5 \%$, lemak $0,8 \%$, abu $7,8 \%$, karbohidrat $53,3 \%$ dan air 3,6\%. Tepung kedelai didapat dari supermarket di Bengkulu produksi industri rumah tangga (komposisi tidak tercantum).

Peubah yang diamati adalah $\mathrm{pH}$, Daya Mengikat Air, kekerasan, stabilitas warna (nilai L, a dan b) dan susut masak.

Tahapan pembuatan sosis disajikan pada gambar berikut :

\section{Pengukuran Variabel :}

1. $\mathrm{pH}$

Pengukuran $\mathrm{pH}$ dilakukan dengan menggunakan $\mathrm{pH}$ meter dengan cara sampel sosis sebanyak 5 gram dimasukkan ke dalam gelas beker, diencerkan dengan aquades sampai $50 \mathrm{ml}$ kemudian dihomogenkan dengan mixer selama 1 menit. Sebelum $\mathrm{pH}$ diukur, $\mathrm{pH}$ meter dikalibrasi dengan buffer $\mathrm{pH} 4$ dan buffer $\mathrm{pH} \mathrm{7,} \mathrm{setelah} \mathrm{itu} \mathrm{dilakukan} \mathrm{pengukuran}$ $\mathrm{pH}$ daging dengan menempatkan elektroda pada sampel dan nilai $\mathrm{pH}$ tertera pada layar $\mathrm{pH}$ meter.

\section{Daya Mengikat Air (DMA)}

Daya mengikat air diuji dengan metode penekanan (Press method) sesuai dengan petunjuk Hamm (Soeparno, 1994) yaitu dengan membebani 0,3 gram sampel daging pada kertas (filter) diantara dua

Tabel 1. Komposisi bahan-bahan pembuatan sosis

\begin{tabular}{llc}
\hline No & Bahan-bahan & Komposisi \\
\hline 1 & Nikumi (surimi-like) & $300 \mathrm{~g}$ \\
2 & Binder (susu skim + tepung kedelai) & $6 \%$ \\
3 & Tepung sagu & $10 \%$ \\
4 & Tepung gandum & $15 \%$ \\
5 & Garam & $2 \%$ \\
7 & STTP & $0,2 \%$ \\
8 & Merica & $0,5 \%$ \\
10 & Pala & $0,3 \%$ \\
11 & Bawang Putih & $1,5 \%$ \\
12 & Es batu & $25 \%$ \\
\hline
\end{tabular}


plat dengan beban seberat $35 \mathrm{~kg}$. Setelah 15 menit, daerah tertutup sampel daging dan daerah basah disekitarnya ditandai dan diukur dengan planimeter. Daerah basah adalah luas daerah penyerapan air pada kertas saring setelah dijepit selama 5 menit dikurangi dengan daerah tertutup sampel daging. Daya mengikat air dihitung dengan rumus berikut :

$$
\mathrm{Mg} \mathrm{H} \mathrm{H}_{2} \mathrm{O}=\frac{\text { Daerah basah }\left(\mathrm{cm}^{2}\right)}{0,0948}-8,0
$$

Angka yang diperoleh dengan rumus tersebut kemudian dikonversi terhadap berat sampel 3,0 gram. Bila nilai yang diperoleh makin besar, maka daya mengikat air makin rendah.

\section{Susut Masak (Cooking loss)}

Susut masak diukur dengan menimbang bobot sosis mentah dan bobot sosis masak setelah didinginkan.

Bobot sosis mentah - bobot sosis masak

$\%$ Susut masak =

4. Kekerasan

Pengukuran dilakukan dengan menggunakan alat instron UTM-1140 dengan Load Cell 2512-204 dan ujung penekanan compression type model 2830013. Pengukuran dilakukan sebanyak 2 kali, penekanan pertama hanya sampai sosis tepat akan pecah, kemudian dilakukan penekanan kedua. Respon dari kekerasan yang dihasilkan ditampilkan dalam grafik skala. Nilai kekerasan dinyatakan dalam tinggi grafik maksimal dengan satuan $\mathrm{kg} / \mathrm{kg}$.

\section{Warna (Apriantono et al, 1998)}

Pengukuran dilakukan dengan alat chromameter dengan parameter $\mathrm{x}, \mathrm{y}$ dan $\mathrm{Y}$. Sebelum digunakan alat dikalibrasi terlebih dahulu dengan stándar warna yang mendekati warna sosis konstanta $(Y=25,30$; $\mathrm{x}=0,3630$ dan $\mathrm{y}=0,3360$ ). Nilai $\mathrm{x}, \mathrm{y}$ dan $\mathrm{Y}$ yang tertukar akan didapat nilai $\mathrm{L}, \mathrm{a}$ dan $\mathrm{b}$ melalui persamaan :

$$
\begin{aligned}
& Y=y, \quad x=Y(y / x), z=Y(1-x-y) / y \\
& L=10 Y^{1 / 2} \\
& a=17,5(1,02 X-Y) / Y^{1 / 2} \\
& b=7,0(Y-0,847 Z) / Y^{1 / 2}
\end{aligned}
$$

Nilai L menunjukkan parameter kecerahan dengan nilai 0 (hitam) sampai 100 (putih). Nilai a menyatakan warna kromatik campuran merah dan hujan dengan nilai $0-100$ untuk warna merah dan 0- (-80) untuk warna hijau, sedangkan nilai $b$ menyatakan nilai kromatik campuran biru dan kuning dengan nilai 070 untuk warna biru dan 0-(-70) untuk warna kuning. Pengukuran dilakukan pada permukaan contoh sosis dengan cara terlebih dahulu membuka selongsong sosis.

\section{Rancangan Percobaan}

Percobaan menggunakan rancangan acak kelompok pola searah dengan perlakuan komposisi binder yang terdiri dari empat perlakuan dan tiga ulangan. Untuk menguji pengaruh perlakuan terhadap respon yang diamati dilakukan analisis ragam dengan menggunakan prosedur General Linier Models (GLM) dari Statistical Analysis System (SAS) Program. Apabila hasil analisis ragam menunjukkan perbedaan yang nyata dilanjutkan dengan uji jarak berganda Duncans (Stell dan Torrie, 1995).

\section{HASIL DAN PEMBAHASAN}

\section{$\mathrm{pH}$}

Subtitusi susu skim dengan tepung kedelai tidak nyata berpengaruh $(\mathrm{P}>0,05)$ terhadap $\mathrm{pH}$ sosis. Kisaran nilai $\mathrm{pH}$ untuk sosis kerbau adalah antara 4,53 - 4,62 dengan rataan 4,56. Nilai $\mathrm{pH}$ hasil 
penelitian ini lebih rendah dibanding nilai $\mathrm{pH}$ yang didapatkan Agawati (2003) yaitu 5,88 - 6,19 dan Suryaningsih (2006) yaitu $6,11-6,77$ dengan rataan 6,49. Rendahnya nilai $\mathrm{pH}$ ini kemungkinan disebabkan oleh bahan baku yang digunakan untuk pembuatan sosis. Nikumi (surimi-like) sebagai bahan baku sosis mempunyai kisaran pH 4,63 - 5,04 (Mega, 2010) lebih rendah dari $\mathrm{pH}$ ultimat daging normal yaitu 5,5 -5,8 (Abustam, 2009a). Rendahnya $\mathrm{pH}$ nikumi dan sosis pada penelitian ini kemungkinan disebabkan oleh daging yang digunakan adalah daging PSE (pale, soft and exudative). Daging PSE terjadi karena adanya denaturasi protein miofibriler yang disebabkan oleh $\mathrm{pH}$ otot dibawah titik isoelektrik sehingga otot menjadi pucat, berair dan strukturnya longgar (mudah terurai). Hal ini bisa terjadi pada ternak yang mengalami stress sangat berat menjelang disembelih dan akibatnya proses rigor mortis berlangsung sangat cepat (Aberle et al, 2001).

\section{Daya Mengikat Air}

Daya mengikat air diartikan sebagai kemampuan daging untuk mempertahankan kandungan airnya selama mengalami perlakuan seperti pemotongan, pemanasan, penggilingan dan pengolahan. Subtitusi susu skim dengan tepung kedelai sangat nyata $(\mathrm{P}<0,01)$ mempengaruhi daya mengikat air sosis kerbau. Daya mengikat air untuk sosis kerbau berkisar antara 83,81\% $94,28 \%$ dengan rataan $89,99 \%$. Semakin besar persentase subtitusi susu skim oleh tepung kedelai daya mengikat air sosis kerbau cenderung meningkat. Menurut Bouton et al (1971) dan Wismer-Pedersen (1971) dalam Abustam (2009), daya mengikat air oleh protein daging dipengaruhi oleh $\mathrm{pH}$. Nilai $\mathrm{pH}$ yang didapat pada penelitian ini berada di bawah titik isoelektrik $(5,0-5,2)$ akibatnya terjadi kelebihan muatan positif, pada kondisi ini muatan positif protein daging akan menarik muatan negatif untuk molekul air $(\mathrm{OH})$ sehingga meningkatkan daya mengikat air. Ini sesuai dengan yang dikemukakan oleh Aberle et al (2001), pada saat $\mathrm{pH}$ lebih rendah dari titik isoelektrik protein-protein daging akan terjadi kelebihan muatan positif yang mengakibatkan penolakan miofilamen dan akan memberi ruang yang lebih banyak bagi molekul-molekul air. Ada tiga bentuk ikatan air di dalam otot yakni air yang terikat secara kimiawi oleh protein otot sebesar $4-5 \%$ sebagai lapisan monomolekuler pertama, kedua air terikat agak lemah sebagai lapisan kedua dari molekul air terhadap grup hidrofilik, sebesar kira-kira 4\%, dimana lapisan kedua ini akan terikat oleh protein bila tekanan uap air meningkat. Ketiga adalah adalah lapisan molekul-molekul air bebas diantara molekul protein, besarnya kira-kira $10 \%$. Denaturasi protein tidak akan mempengaruhi perubahan molekul pada air terikat (lapisan pertama dan kedua), sedang air bebas yang berada diantara molekul akan menurun pada saat protein daging mengalami denaturasi (WismerPedersen, 1971) dalam Abustam (2009b).

\section{Kekerasan}

Berdasarkan hasil pengukuran kekerasan objektif dengan Instron UTM1140, nilai kekerasan sosis kerbau berkisar antara $0,13-0,31 \mathrm{~kg} / \mathrm{mm}$ dengan rataan $0,25 \mathrm{~kg} / \mathrm{mm}$. Hasil analisis ragam menunjukkan bahwa subtitusi susu skim oleh tepung kedelai sangat nyata $(\mathrm{P}<0,01)$ mempengaruhi kekerasan sosis kerbau. Peningkatan jumlah penggunaan tepung kedelai cenderung menurunkan kekerasan sosis. Hasil penelitian ini sejalan dengan hasil penelitian Suryaningsih (1997) dengan nilai kekerasan 0,24 -0,46 kg/mm. Menurut Indarmono (1987) dalam Ulupi et al (2005), kekerasan ditentukan oleh tingkat kerapatan struktur matriks yang terbentuk 
akibat pemanasan. Semakin tinggi kerapatan struktur matrik, maka semakin tinggi nilai kekerasan. Substitusi susu skim oleh tepung kedelai menurunkan karapatan struktur matrik sehingga sosis menjadi lebih empuk. Selain itu kekerasan dipengaruhi oleh kadar air, lemak dan protein (Kramlich, 1971) serta jenis dan jumlah tepung (Pandisurya, 1983 dalam Ulupi et al , 2005). Salah satu sifat fungsional protein dalam sistem makanan adalah pembentukan dan penstabilan emulsi lemak (Padmawinata, 1997)

\section{Susut masak}

Susut masak sosis adalah berat yang hilang selama proses pemasakan. Susut masak yang tinggi menandakan bahwa kemampuan emulsi dalam mengikat air dan lemak kecil. Susut masak pada proses pengolahan sosis merupakan salah satu faktor yang dapat mempengaruhi nilai ekonomi. Hasil uji DMRT menunjukkan bahwa subtitusi susu skim oleh tepung kedelai sangat nyata $(\mathrm{P}<0,01)$ menurunkan susut masak sosis kerbau. Dari Tabel 2 diatas terlihat bahwa semakin tinggi subtitusi susu skim oleh tepung kedelai susut masak semakin rendah, ini artinya penggunaan protein tepung kedelai sebagai bahan pengikat (binder) mampu menurunkan susut masak sosis. Salah satu yang mempengaruhi susut masak adalah daya mengikat air. Daya mengikat air sosis meningkat dengan substitusi susu skim oleh tepung kedelai (Tabel 2), sehingga susut masak sosis menurun. Hal ini sesuai dengan pendapat Ockerman (1983), susut masak sangat dipengaruhi oleh hilangnya air selama pemasakan, keadaan ini dipengaruhi oleh protein yang dapat mengikat air, semakin banyak air yang ditahan oleh protein maka semakin sedikit air yang keluar sehingga susut masak berkurang. Padmawinata (1997) menyatakan sifat fungsional protein dalam menyerap dan mengikat air adalah dengan cara pengikatan hidrogen dengan air dan pemerangkapan air.

\section{Nilai Kecerahan (Warna L)}

Nilai kecerahan sosis merupakan nilai L hasil pengukuran stabilitas warna sosis dengan alat chromameter Minolta CR-300. Nilai L yang semakin tinggi menunjukkan warna sosis semakin cerah. Subtitusi susu skim oleh tepung kedelai sebagai binder tidak berpengaruh nyata $(\mathrm{P}>0,05)$ terhadap kecerahan sosis kerbau. Kisaran nilai L untuk sosis kerbau 55,58 59,07 dengan rataan 56, 73. Hasil penelitian Agawati (2003) menyebutkan nilai L untuk sosis sapi adalah 61,40 - 63,91 dengan rataan 63,03 sedangkan hasil penelitian Suryaningsih (1997) menyebutkan kisaran nilai kecerahan sosis sapi antara 42,37 48,19 dan kecerahan warna sosis yang ada di pasaran antara 47,64 - 54,69. Meskipun tidak berbeda nyata, tingkat kecerahan sosis kerbau dalam penelitian ini cenderung menurun dengan semakin tingginya level tepung kedelai. Secara visual warna tepung kedelai adalah kuning kecoklatan sedangkan warna susu skim adalah kuning muda terang. Sehingga semakin banyak substitusi susu skim oleh tepung kedelai menyebabkan kecerahan sosis cenderung menurun.

\section{Intensitas Warna Merah (Nilai a)}


Tabel 2. Rataan nilai pH, daya mengikat air (DMA), kekerasan, susut masak dan warna sosis kerbau

\begin{tabular}{|c|c|c|c|c|c|}
\hline \multirow[b]{2}{*}{ Variabel } & \multicolumn{4}{|c|}{ Susu Skim : Tepung kedelai (\%) } & \multirow[b]{2}{*}{ Rataan } \\
\hline & $6: 0$ & $4: 2$ & $2: 4$ & $0: 6$ & \\
\hline $\mathrm{pH}$ & 4,62 & 4,55 & 4,54 & 4,53 & 4.56 \\
\hline DMA (\%) & $83,81^{c}$ & $94,28^{a}$ & $90,71^{\mathrm{b}}$ & $91,17^{a b}$ & 89.99 \\
\hline Kekerasan $(\mathrm{kg} / \mathrm{mm})$ & $0,31^{\mathrm{a}}$ & $0,26^{\mathrm{b}}$ & $0,26^{\mathrm{b}}$ & $0,18^{c}$ & 0.25 \\
\hline Susut Masak (\%) & $7,20^{a}$ & $5,17^{b}$ & $4,53^{\mathrm{b}}$ & $2,53^{c}$ & 4,86 \\
\hline Nilai L & 58,07 & 57,09 & 56,18 & 55,58 & 56.73 \\
\hline Nilai a & 2,58 & 2,66 & 3,16 & 5,43 & 3.46 \\
\hline Nilai b & 6,40 & 6,39 & 6,41 & 7,08 & 6.38 \\
\hline
\end{tabular}

Keterangan: Angka yang diikuti huruf kecil yang berbeda pada baris yang sama menunjukkan perbedaan sangat nyata $(\mathrm{P}<0,01)$

Nilai a merupakan warna kromatik campuran warna merah dan hijau dengan nilai (+) a dari 0-100 untuk warna merah dan nilai (-) a dari $0-(-80)$ untuk warna hijau. Nilai a yang semakin tinggi menunjukkan warna sosis semakin merah. Berdasarkan hasil analisis ragam intensitas warna merah sosis kerbau tidak berpengaruh nyata $(P>0,05)$ dengan adanya substitusí susu skim oleh tepung kedelai. Tabel 2 menunjukkan rataan intensitas warna merah pada sosis kerbau 2,58 - 5,43 dengan rataan 3,46. Semakin besar substitusí susu skim oleh tepung kedelai intensitas warna merah cenderung meningkat. Hal ini diduga disebabkan oleh warna tepung kedelai lebih gelap dibandingkan warna susu skim, sehingga warna sosis yang mengandung tepung kedelai lebih banyak cenderung lebih gelap. Susu skim berwarna kuning muda sedangkan tepung kedelai berwarna kuning kecoklatan.

\section{Intensitas Warna Kuning ( Nilai b)}

Nilai b merupakan warna kromatik campuran warna biru dan kuning dengan nilai $(+)$ b dari $0-70$ untuk warna kuning dan (-) b dari $0-(-70)$ untuk warna biru. Nilai b yang semakin tinggi menunjukkan warna sosis yang semakin kuning. Hasil analisis ragam menunjukkan bahwa subtitusi susu skim oleh tepung kedelai tidak nyata $(\mathrm{P}>0,05) \quad$ mempengaruhi intensitas warna kuning sosis kerbau.

Intensitas warna kuning sosis kerbau berkisar antara 6,39-7,11 dengan rataan 6,58. Semakin tinggi level subtitusi susu skim oleh tepung kedelai intensitas warna kuning pada sosis kerbau meningkat pada subtitusi susu skim oleh tepung kedelai $6 \%$. Intensitas warna kuning sosis pada penelitian ini jauh lebih rendah dibandingkan yang didapatkan oleh Suryaningsih (1997), yang berkisar antara 22,11 - 28,68 dan mendekati hasil penelitian Agawati (2003) yang berkisar antara 6,99 - 8,20 dengan rataan 7,60. Rendahnya intensitas warna kuning pada penelitian ini diduga disebabkan oleh rendahnya kandungan lemak sosis akibat proses leaching yang dilakukan pada bahan baku nikumi. Menurut Pujiharjo (2002) warna kuning pada sosis berasal dari lemak daging maupun dari lemak tambahan yang terikat.

\section{SIMPULAN}

Substitusi susu skim oleh tepung kedelai meningkatkan daya mengikat air, menurunkan susut masak dan kekerasan objektif. Daya mengikat air pada level substitusi $2 \%(94,28 \%), 4 \%(90,71 \%)$ dan $6 \%$ $(91,17 \%)$ dan tanpa subtitusi $(83,81 \%)$. Nilai kekerasan sosis berturut-turut, P1 $(0,31$ $\mathrm{kg} / \mathrm{mm})$, P2 dan P3 $(0,26 \mathrm{~kg} / \mathrm{mm})$ dan P4 $(0,18 \mathrm{~kg} / \mathrm{mm})$ sedangkan susut masak untuk P1 (7,20\%), P2 (5,17\%), P3 (4,53) dan P4 $(2,53)$. Substitusi susu skim oleh tepung kedelei tidak berpengaruh terhadap nilai $\mathrm{pH}$. Intensitas warna merah (nilai a) dan kuning (nilai b) cenderung meningkat 
dengan semakin tingginya level subtitusi susu skim dengan tepung kedelai, sebaliknya kecerahan (nilai L) cenderung menurun.

\section{DAFTAR PUSTAKA}

Aberle, E.D., J.C. Forrest, D.E. Gerrard and E.W. Mills. 2001. Principles of Meat Science. Fourth Ed. Kendal/Hunt Publishing Company. Amerika.

Abustam, E. 2009a. Konversi Otot Menjadi Daging. Modul II. Materi Kuliah Dasar Teknologi Hasil Ternak. Fakultas Peternakan Universitas Hasanuddin, Makasar.

Abustam, E. 2009b. Sifat-sifat Daging Segar. Modul III. Materi Kuliah Dasar Teknologi Hasil Ternak. Fakultas Peternakan Universitas Hasanuddin, Makasar.

Agawati. 2003. Sifat fisiko-kimia sosis daging kuda dan sapi dengan substitusi kasein oleh susu skim sebagai binder [tesis]. Institut Pertanian Bogor. Bogor.

[AOAC] Official Methods of Analysis of the Association of Official Analytical Chemist. 1995. Washington D.C., USA.

Apriyantono, A., D. Fardias, N.L. Puspitasari, Sedarnawati dan S. Bidiyanto. 1989. Analisis Pangan. Pusat Antar Universitas Pangan dan Gizi Institut Pertanian Bogor. IPB Press, Bogor.

Dirjen Bina Produksi Peternakan, 2004. Pokok-pokok pemikiran tentang pembangunan peternakan 2005-2009. Departemen Pertanian RI,Jakarta.

Mega, O. 2010. Beberapa Sifat Fisiko Kimia Nikumi (Surimi-like) Kerbau dengan Beberapa Level Sukrosa Sebagai Antidenaturan. Prosiding Seminar Nasional dan Rapat Tahunan Dekan (Semirata) Bidang Ilmu Pertanian BKSPTN Wilayah Barat. Fakultas Pertanian
Universitas Bengkulu 23-25 Mei 2010, Bengkulu.

Padmawinata, K 1997. Kimia Makanan. Penerbit ITB, Bandung. Terjemahan dari ; Principles of Food Chemistry , deMan. 1989,Van Nostrand Reinhold.

Ockerman, H.W. 1983. Chemistry of Meat Tissue. $10^{\text {th }}$ Ed. Departement of Animal Science The Ohio State University and The Ohio Agriculture Research and Development Centre, Ohio.

Pujoharjo, A. 2002. Karakteristik sosis daging kelinci dan ayam dengan tingkat penggunaan tapioka dan susu skim yang berbeda. Skripsi. Fakultas Peternakan. Institut Pertanian Bogor, Bogor.

Soeparno. 1998. Ilmu dan Teknologi Daging. Gadjah Mada Univ Press, Yogyakarta.

Steel, R.G.D dan J.H. Torrie. 1995. Prinsip dan Prosedur Statistik. Suatu Pendekatan Biometrik. Edisi Kedua. Gramedia, Jakarta.

Sugiharso, C. 1982. Mempelajari pengaruh jenis dan jumlah penambahan minyak/lemak pada pembuatan pasta dari jengger udang [skripsi]. Institut Pertanian Bogor, Bogor.

Suryaningsih, L. 1997. Pengaruh daging tetelan, samcan, dan punuk dari bangsa sapi Australian Commercial Cross terhadap pembentukan sosis. Tesis. Program Pascasarjana Institut Pertanian Bogor, Bogor.

Suryaningsih, L. 2006. Pengaruh jenis daging, antidenaturan dan natrium tripolifosfat pada nikumi terhadap karakteristik prroduk daging olahan. Disertasi. Sekolah Pasca Sarjana Institut Pertanian Bogor, Bogor.

Ulupi, N., Komariah dan S. Utami. 2005. Evaluasi penggunaan garam dan sodium tripoliphosphat terhadap sifat fisik bakso sapi. JPPT Vol 30 (2) : 88-95 